\title{
I knew it all along! Evaluating time-of-decision measures in the 2008
}

\section{U.S. presidential campaign}

Lauren Kogen

Jeffrey A. Gottfried

This is an Accepted Manuscript of an article published in Political Behavior, available online: http://dx.doi.org/10.1007/s11109-011-9182-9

Abstract: This paper evaluates the two most common methods of measuring voter time-ofdecision - the recall method and the panel method - and asks whether the two methods are consistent with each other. Using data from the National Annenberg Election Survey collected during the 2008 U.S. presidential election, the findings suggest that these two methods measure different concepts, and thus cannot be used interchangeably. Furthermore, discrepancies between the two methods suggest that the accepted model of early, campaign, and late decision-making should be adjusted to account for a fourth group of voters that never changes their vote intention, but does not truly commit to that intention until later in the campaign. The concept of uncommitted early deciders is offered to describe this group, created by combining the two methods.

Keywords: Elections, campaigns, voting behavior, methodology, public opinion, survey

To cite: Kogen, L. and Gottfried, J.A. (2012). I knew it all along! Evaluating time-of-decision measures in the 2008 U.S. presidential campaign. Political Behavior, 34(4), 719-736. 
During an election campaign, a voter's final candidate choice is based on a host of factors, including the candidates' policy stances and voter partisanship. The timing of that decision depends on several factors as well, and reveals information not only about the attributes of the voter, but also about the electorate as a whole and the likely effectiveness of election campaigns. Early studies of political campaigns found that decision timing generally fell into two categories, with voters choosing their candidate either very early in the campaign or very close to Election Day. The early deciders, who made up the majority of voters, were found to be highly partisan and more informed about relevant campaign issues (Berelson, Lazarsfeld, and McPhee 1954; Campbell, Converse, Miller, and Stokes 1960; Lazarsfeld, Berelson, and Gaudet 1944), while late deciders were found to be unpredictable with respect to vote choice, inattentive to the campaign and the media, and ill-informed about the issues. This created two concerns about the state of American democracy: if the majority of voters decided before the campaign, then this would render campaigns and debates generally irrelevant, and if the ultimate outcome (in close elections at least) was determined by late deciders, then this would mean a heavy responsibility is placed on those who are the least informed and engaged.

Recent changes in social practices and media technologies suggest trends both toward earlier and later decision-making in the electorate. On one hand, it has been argued that a rise in education levels nationally and an increase in exposure to media and campaign information among citizens has led to an electorate that is more informed, more interested in politics, and more likely to base vote choice on campaign information than party affiliation (Chaffee and Choe 1980; Dalton and Wattenberg 2000; Dalton 2007; Fournier, Nadeau, Blais, Gidengil, and Nevitte 2004; Nie, Virba, and Petrocik 1976; Norris, Curtice, Sanders, Scammell, and Semetko 1999). In other words, voters are taking more time to weigh various attributes of the candidates 
and their policy positions, coming to a vote choice later in the election (Chaffee and Rimal 1996; Dalton 2007; Norris et al. 1999).

On the other hand, scholars (e.g. Prior 2005; 2007) have argued that increased access to media has the opposite effect. With greater availability of various media, those who are interested in news seek it out, while those who are not interested in news avoid it entirely. Furthermore, among those that do seek out news, the large number of media outlets available allows them to find media that echo their own point of view, thereby reinforcing ideological dispositions (Jamieson and Cappella 2008; Nir and Druckman 2008; Sunstein 2002). If this is true, it would not be likely that voters are delaying their vote decisions, as suggested by those who claim partisanship is declining. Rather, it suggests that party and ideological affiliations that remain strong lead to early decisions based purely on party identification and not on an openminded analysis of the candidates' platforms.

Time-of-decision is therefore a key variable with respect to studying decision-making processes during election campaigns. It has been used by scholars seeking to understand various aspects of vote decisions, including campaign and media effects (Bowen 1994; Chaffee and Choe 1980; Norris et al. 1999; Whitney and Goldman 1985), the power of partisanship in vote choice (Berelson et al. 1954; Campbell et al. 1960; Dalton 2007; Lazarsfeld et al. 1944), and voters' levels of political knowledge (Dalton 2007; Katz 1971; Zaller 2004).

Crucially, however, methods for measuring time-of-decision are inconsistent. Researchers typically use one of two methodologies to measure this concept: either asking respondents their vote intention at different times during an election campaign, and seeing if and when their intentions change (the panel method), or asking respondents a post-election recall question, in which they are asked to remember when they made up their mind regarding which 
candidate to vote for (the recall method). Additionally, some scholars have expressed doubt as to whether the recall method (the more common method), is even a valid way to operationalize the concept.

This paper analyzes both methods in the context of the 2008 U.S. presidential campaign. Rather than making a determination as to which measure is superior, we argue that both measures are useful, but that each taps a distinct concept regarding when voters came to a vote choice. Therefore, researchers need to be cognizant of the distinctions between the two measures when choosing a methodology, or when using the resulting data to come to conclusions about the electorate. From an analysis of both measures, we argue that combining both measures into a single measure provides a more nuanced understanding of when voters decide and how committed they are in their vote intentions. This analysis reveals that beyond the traditional categories of "early," "campaign," and "late" deciders, there is also a group of voters who never changed their vote choice, but were not set on who they would vote for until later, aptly named "uncommitted early deciders." In addition, we examine what predicts having been an "early," "campaign," or "late" decider according to the panel and recall methods, and an "uncommitted early" decider in the combined method.

\section{Previous time-of-decision studies}

Early election studies, as stated above, typically categorized decisions as either "early" or "late". This two-part model stemmed from studies such as The People's Choice (Lazarsfeld et al. 1944), which asked for respondents' vote intentions before and during the campaign, and found that the majority of the electorate made their decision based on party identification before the start of the campaign. Later studies confirmed this finding (Berelson et al. 1954; Campbell et al. 
1960). In these earlier studies, the electorate was divided dichotomously into stable early deciders and unstable late deciders, the former, as noted above, making up the majority of the electorate, and the latter being characterized as "not particularly interested" in politics (Berelson et al. 1954, p. 20).

In the mid to late 1970 s however, this dichotomous model of early and late deciding was questioned, and a more nuanced model emerged. This shift occurred for three reasons. The first was the belief that partisanship was decreasing and playing less of a role in voting decisions. Nie et al (1976) determined that partisanship began a steep decline after the 1964 election, evidenced by the rising number of independents: "By the 1970s those who consider themselves partisans are more likely to be weak than strong partisans. The figures indicate a clear erosion of the strength of party affiliation in the American public" (p. 49).

A second reason for this shift was an increased attention by scholars to media effects during campaigns. Some attributed the decline in partisanship to the rising ubiquity of television and the resulting access to information other than party affiliation (Chaffee and Choe 1980; Katz 1971). In contrast to the early days of limited information channels, "today's voter would have to go to some lengths to avoid exposure to the many political advertisements and newscasts that are broadcast” (Chaffee and Choe 1980, p. 55). This echoes Katz's (1971) sentiment that a "combination of a low degree of [party] loyalty and yet some exposure to election communications has become a more probable combination in the era of television than ever before" (p. 307). A third reason was the increased use of panel data in understanding time-ofdecision measures. Brody and Rothenberg (1988), for example, found higher levels of voter switching than had previously been found, attributing the change to higher attention paid to candidates and campaign issues as presented in the media. 
While most of these observations were not directly based on time-of-decision information, these trends led to the conclusion that the dichotomous model of early and late deciders was too broad to capture the changing nature of time-of-decision. Eventually, scholars began sorting voters into three categories: early deciders, campaign deciders, and late deciders.

\section{The three-part model}

Early Deciders. Most political scholars consistently find that early deciders are highly partisan (Chaffee and Choe 1980; Chaffee and Rimal 1996; Dalton 2000, 2007; Fournier et al. 2004; Nie et al. 1976), better educated (Chaffee and Choe 1980; Mendelsohn and O'Keefe 1976), and of higher SES (Mendelsohn and O'Keefe 1976) than campaign or late deciders. A few studies, however, do not find a significant difference in income or education for early and campaign deciders (Fournier et al. 2004).

Campaign Deciders. While the dichotomous model seemed to produce reliable proportions of early and late deciders (many early deciders and few late deciders) the addition of campaign deciders complicates the composition of characteristics attributable to each group. With regard to media consumption, some studies found that early deciders pay more attention to the media than campaign deciders (Fournier et al. 2004; Nie et al. 1976), while others show that it is actually campaign deciders that pay the most attention (Chaffee and Choe 1980; Chaffee and Rimal 1996). With regard to partisanship, some who found evidence of declining partisanship also found that these less partisan voters were paying more attention to the election and the mass media, delaying their vote choice, and basing their decision on campaign specific information, rather than on latent party identification, hence becoming campaign deciders (Dalton 2000, 2007; Fournier et al. 2004; Nie et al. 1976). Other studies have suggested that the campaign deciders 
are actually the least partisan, with both early and late deciders relying on party cues to make their decision (Chaffee and Choe 1980; Chaffee and Rimal 1996; Dalton 2007).

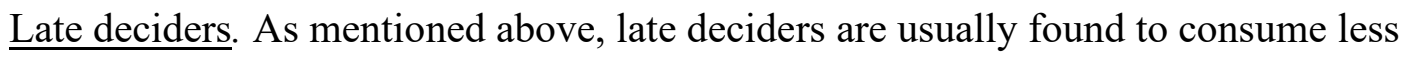
media than campaign or early deciders, and there is mixed evidence as to whether late deciders are more partisan than campaign deciders. In addition, some studies have found late deciders to be the least educated and the least knowledgeable about relevant campaign issues (Chaffee and Choe 1980; Hayes and McAllister 1996) while others have not (Chaffee and Rimal 1996; Nir and Druckman 2008).

\section{"Recall” vs. "Panel” methods}

Because of the concept's multiple uses and perceived importance, three previous studies (Chaffee and Rimal 1996; Fournier et al. 2004; Plumb 1986) have tested the consistency of the recall and panel methods. All three studies assumed a priori that the "panel method" of measuring time-of-decision, in which voters are asked their vote intention at several points throughout the campaign, was a superior operationalization of the concept, and that the "recall method," in which voters are asked to remember their time-of-decision post-election, was the inferior method. Two of the three studies sought to validate the time-of-decision recall measure by comparing it to the panel measure. The studies produced mixed results. One concluded that the recall method was valid, meaning that both methodologies produced consistent results (Fournier et al. 2004), while the other two found that the recall method produced data that diverged from the panel method (Chaffee and Rimal 1996; Plumb 1986). Further complicating the picture, the biases in the measure found in the latter two studies, with respect to early decision making in a presidential election, were in opposite directions, with the number of early 
deciders being overstated (Plumb 1986) or understated (Chaffee and Rimal 1996) by the recall method in comparison to the panel method. Plumb's (1986) study showed that by the recall method $51 \%$ of the electorate stated they had "known all along," while analysis of panel data showed that only $34 \%$ had decided before the campaign, a result in stark contrast to earlier findings and lending support to the hypothesis of some scholars outlined above that late vote decisions are becoming more common. Chaffee and Rimal (1996), however, found that early deciders were underrepresented by voter recall methods, with 39\% claiming pre-campaign decisions, compared to $51 \%$ who were classified as early deciders when using panel data. This finding is much closer to that of early election studies (e.g. Berelson et al. 1954).

The different contexts in which each of these studies was conducted may account for the inconsistent results. Fournier et al's (2004) study was conducted in Canada, in which campaigns are substantially shorter than in the United States. ${ }^{1}$ This also meant the investigators used only two waves of data - before and after the election - and had to use an alternative method of differentiating between campaign and late deciders. Chaffee and Rimal's (1996) analysis of the 1992 U.S. presidential election was sampled only in California, and was complicated by a prominent third party candidate, Ross Perot, who dropped out of the race in July and re-entered in October, which may have created more candidate switching and ambivalence than would have otherwise taken place in a standard two-party election. Plumb's (1986) study took a national sample of the electorate during the 1980 U.S. presidential campaign, but the penultimate wave of data was collected only in September, still quite far ahead of the November $4^{\text {th }}$ Election Day, which may have made it difficult to distinguish between campaign and late deciders.

Several explanations have been given for the discrepancies found between recalled timeof-decision and panel-measured time-of-decision (see Plumb 1986). First, it may be difficult for

\footnotetext{
${ }^{1}$ In Fournier et al's (2004) study, the campaign's length in Canada was only 36 days.
} 
respondents to remember when the decision was made, especially if asked several months after the fact. Second, this disparity might arise as a result of cognitive dissonance, such that partisans who ultimately vote for their own party's candidate may actually think that they knew all along for whom they would vote, even though they may have been undecided at some point during the campaign. Third, desirability bias might deter some from admitting they waited until the last minute to decide (if a delayed decision resulted from insufficient attention paid to the campaign) or from admitting they decided early (if they want to maintain an appearance of party independence and neutrality).

Given the differences found between studies which have examined time-of-decision both in an effort to understand campaigns and to validate the measure itself, two overarching research questions emerge in the context of the 2008 U.S. presidential election:

RQ1: How consistent is the time-of-decision recall method with the panel method and how can we account for inconsistencies between the two methods?

RQ2: What are the predictors of time-of-decision using each method and do they differ from what researchers have found in the past?

The 2008 election provides an opportune moment to study voters' time-of-decision. First, there was no incumbent candidate, either presidential or vice presidential, running in this election, which could artificially inflate the number of early decisions if voters had strong feelings about the candidate's first term. This election also saw a high level of voter interest (Pew 2008a), including high levels of media attention (Pew 2008b) and increased voter turnout (Murray 2008). Thus, the effects of the media and the campaign on vote timing, if there are any, should be found here. 
In the present research we will see that, according to both the panel and recall methods, early deciders continue to make up a majority of the electorate, though the panel method categorizes far more voters as early deciders. However, unlike previous studies which have assumed that the panel method provides the 'correct' data and that the recall measure is a (potentially inadequate) substitute, we oppose interpreting this difference between the two as justification for a dismissal of the recall question in toto. Rather, our analysis shows that the recall and panel methods may in fact be tapping two distinct concepts. We base our argument on the analysis of three variables that have typically been used to evaluate time-of-decision: partisanship, level of campaign knowledge, and media consumption.

\section{Methods}

This study uses data from the internet component of the 2008 National Annenberg Election Survey (NAES), funded by the Annenberg Public Policy Center at the University of Pennsylvania. The analyses draw on data from the last three waves of a five wave panel design conducted between October 2007 and January 2009. The third wave was fielded between April 1, 2008 and August 28, 2008 (before the election campaign began), the fourth wave between August 29, 2008 and November 4, 2008 (during the campaign), and the fifth wave between November 5, 2008 and January 31, 2009 (after the campaign). The design of the study was a rolling cross-section in which each day new random subsamples (or replicates) of the pool of respondents were asked to complete the survey. ${ }^{2}$ The analysis includes subjects who completed at least the third, fourth, and fifth waves of the panel, completed the third wave after June 6 ,

\footnotetext{
${ }^{2} 617$ replicates were released during the third wave, 635 in the fourth, and 653 in the fifth.
} 
$2008,{ }^{3}$ completed the fourth wave before October $30,2008,{ }^{4}$ and voted in the November 4 election for either Barack Obama or John McCain $(\mathrm{N}=3,963)$.

The data for the NAES internet component were collected by Knowledge Networks. Participants were selected from Knowledge Networks' pool of respondents, who were originally recruited through Random Digit Dialing (RDD), and therefore a national probability sample. ${ }^{5}$ Knowledge Networks provides respondents with WebTV units and internet access for participation in their surveys. Since a random subset from the Knowledge Networks pool was drawn for this study, the NAES utilizes a random sample of the United States adult population. In comparison to telephone RDD surveys, Knowledge Networks samples have been shown to be equally representative of the United States population (e.g., see Berrens, Bohara, Jenkins-Smith, Silva, and Weimer 2003; Krosnick and Chang 2001), and produce less desirability bias than in face-to-face and telephone interviews (Callegaro 2008; Chang and Krosnick 2002).

\section{Measuring time-of-decision}

The panel study provides the opportunity to measure time of vote decision using both of the methodologies described above. The first is the more traditional recall method, which asked respondents with a single item in the fifth wave after the election had occurred, "When did you finally decide for whom to vote in the presidential election?" ${ }^{6} 54.5 \%(\mathrm{~N}=2,173)$ said they were

\footnotetext{
${ }^{3}$ Because a Democratic nominee wasn't decided until June 6, 2008, it was decided to eliminate everyone who completed the third wave before this date.

${ }^{4}$ Because the fourth wave includes the last week of the campaign, it would not have been possible to differentiate whether people who completed the fourth wave within the last week were in fact campaign or late deciders.

${ }^{5}$ The household recruitment rate (RECR) is the percent of respondents recruited using RDD telephone methods who agreed to be in the Knowledge Networks sample; the RECR was $21.0 \%$ for the third wave, $21.2 \%$ for the fourth wave, and $21.0 \%$ for the fifth wave. Of those in the Knowledge Networks sample who were asked to complete the survey, the final cooperation rate was $74.3 \%$ for the third wave, $73.1 \%$, for the fourth wave, and $69.1 \%$ for the fifth wave.

${ }^{6}$ The wording of this question varies somewhat among studies. The ANES survey has changed the wording of this question at least eight times (see Plumb (1986) for question variations through 1980). The current version asks
} 
early deciders (decided before September), 31.6\% $(\mathrm{N}=1,253)$ said they decided during the campaign (decided in September up until late October), and 13.8\% (N=531) said they were late deciders (decided sometime in the last week of the election up until Election Day). These categories roughly correspond to the time points used in other time-of-decision studies.

Respondents were also asked about their vote intentions during the third and fourth waves and vote choice in the fifth wave. In the third and fourth waves, respondents were asked "If the presidential election was held today and Barack Obama and Joe Biden, the Democrats, were running against John McCain and Sarah Palin, the Republicans, who would you vote for?," and in the fifth wave were asked "Who did you vote for?" Using this data, in what will be called the panel method, time-of-decision was determined as occurring whenever a survey respondent stated they intended to vote for Obama or McCain, and did not change their allegiance in subsequent waves. ${ }^{7}$ Thus, if subjects did not change their vote choice throughout the three waves, they were early deciders. If they did not know in the third wave or changed their vote intention between the third and fourth waves, and did not change between the fourth and fifth waves, they were campaign deciders. If they did not know in the fourth wave or changed their vote choice between the fourth and fifth waves, they were late deciders. According to the panel method, $82.9 \%(\mathrm{~N}=3,268)$ were early deciders, $10.1 \%(\mathrm{~N}=390)$ were campaign deciders, and $6.9 \%(\mathrm{~N}=280)$ were late deciders.

\footnotetext{
"How long before the election did you decide that you were going to vote the way you did?" ("American National Elections Studies", 2010); Fournier et al's (2004) study asked "When did you decide that you were going to vote X?" (p. 664); Chaffee and Rimal (1996) asked "When would you say you finally decided for sure which way you were going to vote for president?" (p. 288); Plumb's (1986) study, based on the 1980 National Election Panel Study data, asked "When did respondent reach vote decision?" (p. 310).

${ }^{7}$ This method cannot account for those respondents who changed their minds after an interview, then switched back to their original candidate choice before being interviewed again. These respondents would be coded as consistent. This is, however, the methodology used in time-of-decision studies.
} 
Analysis

Our first research question asks about the consistency between the recall and panel

methods. A cross-tabulation was calculated to estimate the amount of overlap between the two

measures. Concerning the second research question, which asks what predicts time of decision, a multinomial logistic regression model was conducted for both the recall and panel methods. In each of these models, time-of-decision was predicted from party strength, ${ }^{8}$ political knowledge, ${ }^{9}$ and number of news sources consumed during the election, ${ }^{10}$ controlling for age, gender, race, income, education, party identification, presidential vote choice, perception of the economy, and personal financial situation. This analysis provided the ability to test how the different time-ofdecision groups differ from each other for each method.

\section{Results}

\section{Consistency between the two measures}

Table 1 presents the bivariate cross-tabulation between the recall and panel methods. It should first be noted that in both measures, a majority of voters can be classified as early

\footnotetext{
${ }^{8}$ Party strength was measured with a 4 point scale ranging from 0 (does not identify with either party) to 3 (very strongly identifies with either party) $(\mathrm{M}=2.03, \mathrm{SD}=0.89)$.

${ }^{9}$ A knowledge scale was constructed by using survey items that asked respondents to state their positions on the issues of gay marriage, the war in Iraq, and abortion, and items that asked whether they knew which candidate held a position closer to their own position on each issue. Respondents were asked, "which presidential candidates' views are most like your own?" A scale ranging from 0 to 3 was created which indicated how many times the respondent correctly matched their own views with those of the candidate(s) $(\mathrm{M}=1.59, \mathrm{SD}=1.02)$. While not a traditional measure of knowledge, it is a more relevant measure of knowledge for the 2008 election since it measures respondents' ability to correctly locate the candidates' issue stances. Additionally, because the survey was conducted via the internet, there was concern that asking the traditional, more general knowledge question would be less valid because respondents would be more likely to look up the answers online if they knew that their knowledge was being tested. The items used for this measure made it less obvious in the survey that the respondents' knowledge was being tested.

${ }^{10}$ In the fourth wave, respondents were asked, "from which of the following sources have you heard anything about the presidential campaign?" Respondents had the choice of TV news programs, newspapers, TV talk shows, Internet sites, radio, and news magazines. The total number of sources from which they received information from was summed, creating a scale from 0 to 6 sources $(\mathrm{M}=3.56, \mathrm{SD}=1.46)$.
} 
deciders, having decided before September. This is consistent with the previously discussed literature that found that most voters do make up their minds far in advance of Election Day. While this finding is consistent between the two measures, the magnitude of the majority varies quite dramatically. According to the recall measure, $55.0 \%$ of voters were early deciders, while $83.0 \%$ qualified as early deciders according to the panel method. Considering these two figures alone, there is a clear discrepancy. This suggests that many voters made up their minds earlier than they claimed in the recall question.

Next, within table 1, the bolded numbers represent the percentage of respondents in each category of the recall method who matched the same category in the panel method. $94.5 \%$ of early deciders according to the recall method also were early deciders according to the panel method. There is clear evidence that a vast majority of voters who recalled deciding early also decided early according to the panel method. Similar overlap, though, did not occur for the campaign and late deciders. Only $18.2 \%$ of those who recalled having decided during the campaign did so according to the panel method. In fact, $80.2 \%$ of those who recalled having decided during the campaign never changed their vote intention/choice. Additionally, only $42.6 \%$ of those who recalled deciding late in the campaign actually did so according to the panel method. Overall, a total of only $63.5 \%$ of respondents were in the same category for both methods.

\section{[TABLE 1 HERE]}

Because the recall method differed substantially from the panel method, and a large proportion (36.5\%) did not fall into the same category by the two measures, it is important to consider why these two measures diverged. It could simply mean, as previous studies have 
suggested, that the panel method is valid and the recall method is not. Alternatively, if the predictors for being in each group differ, this could suggest that each measure is tapping a distinct concept. In order to test if they were in fact distinct concepts, we analyzed how the characteristics of each group varied, if at all, for each method. Table 2 presents the group means for each type of decider for each of the predictor and control variables. This table also includes the group means for a combined panel and recall method of measuring time of decision which will be discussed further in this section. Table 3 presents the multinomial logistic regression models of the predictors of being an early, campaign, or late decider for both the panel and recall methods.

\section{[TABLE 2 HERE]}

\section{[TABLE 3 HERE]}

The multinomial logistic regression models present clear differences between the two measures. For party strength, it can be seen that, whereas the panel method showed no difference between campaign and late deciders, there were clear variations between all three groups using the recall method. Also, media consumption, as measured by number of news sources consumed, did not predict being in any of the groups for the panel method, whereas for the recall method, as number of sources increased, the likelihood of being an early decider over a campaign $(b=-.10$; $\mathrm{p}<.001)$ or late decider $(\mathrm{b}=-11 ; \mathrm{p}<.01)$ increased. The fact that partisanship and media consumption affected time-of-decision according to the recall method, but not according to the panel method, suggests that responses to the recall question are telling us something unique about the characteristics of voters.

There are also some similarities between the two methods, suggesting that the differences in characteristics between individuals of the two measures should not be overstated. Most 
notably, the level of political knowledge for early, campaign, and late deciders is clear and consistent between the two methods. The more politically knowledgeable a voter was, the greater the likelihood that he/she decided earlier. For both the panel and recall methods, early deciders were the most knowledgeable, followed by the campaign deciders and then the late deciders. Similar patterns between the panel and recall methods also emerge among other variables including race and education. Black voters, for example, were significantly more likely to have been early deciders than campaign or late deciders. Finally, age, income, being a Democrat, and personal financial situation did not differ by time-of-decision for either the recall or panel methods.

\section{The four-part model: Combining the two methods}

How should we interpret the fact that there are notable differences between the time-ofdecision predictors when using the two different methods? From table 3, it is seen that the recall method provides clear differentiations regarding voter characteristics that the panel method does not. Almost one third of the population $(30.9 \%)$ were campaign or late deciders according to the recall method, but qualified as early deciders by the panel method. This group, which will be called uncommitted early deciders, represents an overlap between the panel and recall method, and may account for the lack of differentiation between groups using the panel method.

Just as in table 3, table 4 presents the predictors of being in each group, but this time combines the panel and recall methods to create four distinct groups: early, uncommitted early, campaign, and late deciders. The introduction of the uncommitted early deciders to the analysis provides clear indication that this group is in fact distinct from the three traditional groups.

[TABLE 4 HERE] 
Looking specifically at party strength, political knowledge, and number of news sources, the uncommitted early deciders are distinct from early deciders on all three variables. Uncommitted early deciders were less partisan, less knowledgeable, and consumed fewer news sources than the early deciders. For every one level increase in party strength, the odds of having been an uncommitted early instead of an early decider decreased by $39 \%(b=-.50 ; p<.001)$. Likewise, for every one level increase in political knowledge, the odds decreased by $26 \%(\mathrm{~b}=-$ $.31 ; \mathrm{p}<.001)$, and for every additional news source consumed, the odds decreased by $10 \%(\mathrm{~b}=-$ $.11 ; \mathrm{p}<.001)$. In addition, the uncommitted early deciders were more partisan and more knowledgeable than the campaign and late deciders. For every one level increase in party strength the odds of having been an uncommitted early instead of a campaign or late decider decreased by $42 \%(b=-.55 ; \mathrm{p}<.01)$ and $32 \%(b=-.39 ; \mathrm{p}<.05)$, respectively; for every one level increase in political knowledge, the odds decreased by $36 \%(b=-.44 ; p<.001)$ and $47 \%(b=-.64$; $\mathrm{p}<.001)$, respectively. The uncommitted early deciders did not differ from the campaign and late deciders on the number of news sources consumed.

\section{Discussion}

One important finding is the overwhelmingly large number of voters who seem to have made up their minds before the start of the 2008 campaign according to the panel method: $83 \%$ of the electorate had a preference for a particular candidate before the campaign began, and ultimately voted for that candidate. A disheartening, and perhaps pessimistic, interpretation of this finding would be that only $17 \%$ of the population was open to the proceedings of the campaign. Such an interpretation would corroborate evidence of the continuing strength of 
partisanship in vote choice and the weak effect of the media on ultimate vote choice (e.g. Pool 1963).

However, the preceding analysis suggests an alternative explanation. The findings show that while most voters intended to vote for a particular candidate before the campaign and did not veer from that intention, a large portion of those voters claimed that they decided later. This may mean that this group was less committed to their vote choice than the early deciders as defined by the panel method. One core question that the time-of-decision measure provides clues about, as illustrated above, is which voters may actually be open to changing their minds about candidates during an election, and thus who might be susceptible to campaign effects (Chaffee and Rimal 1996). If this is the case, it is not appropriate to assume that the panel method is the proper, valid measure of time-of-decision, and therefore that the recall method should be discarded if it does not match up with it. Rather, the two methods may be tapping two distinct constructs, such that the panel method indicates a preference for one candidate over another, but that the recall method may be more appropriately thought of as a 'solidification' of that preference.

The importance of this distinction can be illustrated by imagining asking married couples when they knew their spouse was 'the one'. While a successful first date may in retrospect be recalled as the beginning of a long-term relationship, it is unlikely (contrary to love song clichés) that these individuals fell in love at first sight, and instinctively 'knew' from the get-go that they would ultimately marry. More likely, feelings progressed over time, with feelings toward their partners growing more favorable until, at some critical point, the decision was made that they would like to make a permanent commitment. If you were to ask these couples during the early stages of courtship who they thought they were likely to end up spending the rest of their lives 
with, they may very well have stated a preference for their future spouses over other potential mates, but this is not the same thing as a marriage proposal, at which time the individual is (hopefully) sure about their commitment. Likewise, an inconsistency between the panel and recall methods may signify simply that a voter was "falling for" the candidate when the question was asked, but was still "playing the field," so to speak, and was therefore more likely to be open to other candidate-suitors.

In other words, each method has its own distinct merit toward understanding how and when people decide which candidate they will vote for. Using the recall measure may be more appropriate for studies which aim to analyze what makes voters commit to a particular candidate, while panel-based measures may be more appropriate for studies which aim to track decisionmaking processes throughout an election campaign.

However, we can learn the most about voters' decision processes by combining the recall and panel methods, and looking at what differentiated the group which claimed to be deciding later on but had already made up their mind according to the panel method. The new information offered by moving to a four-part model suggests that we have not only moved beyond the 1940s dichotomy of early and late deciders, but that the three-part model is also inadequate, as it assumes a definition of "decision-making" that does not always map onto voters' states of mind.

With regard to the second research question, using the four part model, we find that people who decide closer to Election Day have weaker party strength and less political knowledge (with no difference in party strength found between campaign and late deciders). For media consumption, even though early deciders consumed more media than other groups, everyone else still consumed a substantial amount of media during the campaign, indicating that all groups were well exposed to campaign messages. 
This new group of uncommitted early deciders was less partisan and less knowledgeable than the early deciders, but more knowledgeable and more partisan than the campaign and late deciders. This suggests that there is a large portion of the electorate that may be receptive to campaign messages as they still consume a substantial amount of media, (even if not as much as the early deciders,) are weaker partisans than early deciders, and are moderately politically knowledgeable. This observation corroborates the work of scholars (see Zaller 1992) who have argued that those who are moderately knowledgeable and interested in politics are the most likely to be persuaded in an election because of their likelihood of being exposed to a message and their moderate level of knowledge about the relevant issues. Though our uncommitted early deciders, by definition, did not change their minds during the election, it is plausible that these voters, along with those voters with similar characteristics that did change their mind in waves four and five, were at least more open to changing their minds, as evidenced by the finding that recalled deciding later than the panel method suggested.

Of course, only limited switching occurred in this election, with only $17 \%$ of voters changing their vote intention at some point throughout the election. This may, at least in part, be an artifact of the context of the 2008 election. One distinct element of the 2008 election was its unusually long primary season. Because Barack Obama was not officially the Democratic candidate until June 6,2008, voters had a substantial amount of time to become familiar with the candidates. This could have made voters decide earlier than in previous elections.

It could also be argued that these uncommitted early deciders simply claim that they decided later in the campaign because of a desirability bias, if it is considered normatively more democratic to weigh the issues and the candidates throughout the campaign before coming to a decision. However, two factors suggest that this is not the case. First, if it were the case that 
voters claimed they decided later because of a desirability bias, it would be expected that those who were attentive and knowledgeable would be the most concerned with democratic norms, and would therefore be more likely to succumb to desirability biases. Instead, the findings show that the most knowledgeable and media-attentive group was also the most likely to admit that they decided pre-campaign. Second, because the survey was conducted over the internet, desirability bias is reduced as compared to telephone or face-to-face interviews, as earlier discussed.

Finally, although this analysis lays out the characteristics of several groups of voters, the question of why these voters ultimately choose their preferred candidate remains unanswered. It is left to be seen what, aside from party cues, ultimately makes a voter decide for whom to vote, regardless of when that decision is made. Some scholars have recently argued that those voters who disagree with their party's candidate on a particularly relevant issue are the most likely to defect to the other party (Hillygus and Shields 2008), while others have argued that it is the likeability of the candidate that matters most (Westen 2007).

Future studies, whether they analyze voter time-of-decision or other decision-making processes, must use caution in measuring time-of-decision, and are likely to benefit from using both measures together. As shown in this study, the two most commonly used measures tell us different things about how voters come to decisions during elections, and combining them gives us more insight into when voters truly make a commitment to their candidate. 


\section{Acknowledgements:}

The authors would like to thank Diana Mutz, Richard Johnston, and Michael Delli Carpini for their support and comments throughout this project. Also, gratitude is extended to the many colleagues who have provided advice on this article.

\section{Biographical notes:}

Lauren Kogen is a doctoral candidate at the Annenberg School for Communication at the University of Pennsylvania. Her current work focuses on representations of international humanitarian crises in the Western press.

Jeffrey A. Gottfried is a doctoral candidate at the Annenberg School for Communication at the University of Pennsylvania and a senior researcher of the Annenberg Public Policy Center. 


\section{Works Cited}

American National Election Studies. (2010). The ANES Guide to Public Opinion and Electoral Behavior. Accessed 15 April 2009 from http://www.electionstudies.org/nesguide/toptable/tab9a_3.htm.

Berelson, B., Lazarsfeld, P. F., \& McPhee, W. N. (1954). Voting: A Study of Opinion Formation in a Presidential Campaign. Chicago: University of Chicago.

Berrens, R. P., Bohara, A., Jenkins-Smith, H., Silva, C., and Weimer, D. L. (2003). The advent of internet surveys for political research: A comparison of telephone and internet samples. Political Analysis, 11(1), 1-22.

Bowen, L. (1994). Time of voting decision and use of political advertising: The Slade Gorton-Brock Adams senatorial campaign. Journalism Quarterly, 71(3), 665-675.

Brody, R. A., \& Rothenberg, L. S. (1988). The instability of partisanship: An analysis of the 1980 presidential election. British Journal of Political Science, 18(4), 445-465.

Callegaro, M. (2008). Social desirability. In P. J. Lavrakas (Ed.), Encyclopedia of Survey Research Methods (pp. 825-826). Newbury Park: Sage Publications.

Campbell, A., Converse, P. E., Miller, W. E., \& Stokes, D. E. (1960). The American Voter. New York: John Wiley.

Chaffee, S. H., \& Rimal, R. N. (1996). Time of vote decision and openness to persuasion. In D. Mutz, P. M. Sniderman, \& R. A. Brody (Eds.), Political persuasion and attitude change (pp. 267-291). Ann Arbor: The University of Michigan Press.

Chaffee, S. H., \& Choe, S. Y. (1980). Time of decision and media use during the Ford-Carter campaign. Public Opinion Quarterly 44(1), 53-69. 
Chang, L., \& Krosnick, J. A. (2002). RDD telephone vs. internet survey methodology for studying American presidential elections: Comparing sample representativeness and response quality. Paper presented at the 2002 American Political Science Association Annual Meeting and at Westat.

Dalton, R. J. (2000). The decline of party identifications. In R. J. Dalton \& M. P. Wattenberg (Eds.), Parties Without Partisans: Political Change in Advanced Industrial Democracies (pp. 19-36). Oxford: Oxford University Press.

Dalton, R. J. (2007). Partisan mobilization, cognitive mobilization and the changing American electorate. Electoral Studies 26(2), 274-286.

Dalton, R. J., \& Wattenberg, M. P. (2000). Parties without partisans: Political change in advanced industrial democracies. Oxford: Oxford University Press.

Fournier, P., Nadeau, R., Blais, A., Gidengil, E., \& Nevitte, N. (2004). Time-of-voting decision and susceptibility to campaign effects. Electoral Studies 23(4), 661-681.

Hayes, B. C., \& McAllister, I. (1996). Marketing politics to voters: Late deciders in the 1992 British election. European Journal of Marketing 30(10/11), 127-139.

Hillygus, D. S., \& Shields, T. G. (2008). The Persuadable Voter: Wedge Issues in Presidential Campaigns. Princeton: Princeton University Press.

Jamieson, K. H., \& Cappella, J. N. (2008). Echo Chamber: Rush Limbaugh and the Conservative Media Establishment. Oxford: Oxford University Press.

Katz, E. (1971). Platforms and windows: Broadcasting's role in election campaigns. Journalism Quarterly 48(20), 304-314.

Krosnick, J. A., \& Chang, L. (2001). A comparison of the random digit dialing telephone survey methodology with internet survey methodology as implemented by Knowledge Networks 
and Harris Interactive. Paper presented at the 2001 annual meeting of the American Association of Public Opinion Research, Montreal, Canada.

Lazarsfeld, P. F., Berelson, B., \& Gaudet, H. (1944). The People's Choice. New York: Columbia University Press.

Mendelsohn, H., \& O, Keefe, G. (1976). The people choose a president: Influences on voter decision making. New York: Praeger.

Murray, S. (2008, Nov 5). 2008 could mark highest voter turnout rate since 1968. The Wall Street Journal Online. http://blogs.wsj.com/washwire/2008/11/05/2008-could-mark-highest-voter-turnout-ratesince-1968/. Accessed 15 April 2009.

Nie, N. H., Virba, S., \& Petrocik, J. R. (1976). The Changing American Voter. Cambridge, MA: Harvard University Press.

Nir, L., \& Druckman, J. N. (2008). Campaign mixed-message flows and timing of vote decision. International Journal of Public Opinion Research 20(3), 326-346.

Norris, P., Curtice, J., Sanders, D., Scammell, M., \& Semetko, H. A. (1999). On Message: Communicating the Campaign. Thousand Oaks, CA: Sage.

Pew Research Center for the People and the Press (2008a, July 10). McCain's enthusiasm gap, Obama's unity gap: Likely rise in voter turnout bodes well for democrats. http://people-press.org/reports/pdf/436.pdf. Accessed 15 April 2009.

Pew Research Center for the People and the Press (2008b, Nov 13). High marks for the campaign, a high bar for Obama republicans want more conservative direction for GOP. http://people-press.org/report/471/high-bar-for-obama. Accessed 15 April 2009.

Plumb, E. (1986). Validation of voter recall: Time of electoral decision making. Political 
Behavior 8(4), 302-312.

Pool, I. (1963). The effect of communication on voting behavior. In W. Schramm (Ed.), The Science of Human Communication (pp. 23-64). New York: Basic Books.

Prior, M. (2005). News vs. entertainment: How increasing media choice widens gaps in political knowledge and turnout. American Journal of Political Science 49(3), 577-592.

Prior, M. (2007). Post Broadcast Democracy: How Media Choice Increases Inequality in Political Involvement and Polarizes Elections. Cambridge, MA: Cambridge University Press.

Sunstein, C. (2002). Republic.com. Princeton, NJ: Princeton University Press.

Westen, D. (2007). The Political Brain: The Role of Emotion in Deciding the Fate of the Nation. New York: Public Affairs.

Whitney, D. C., \& Goldman, S. B. (1985). Media use and time of vote decision: A study of the 1980 presidential election. Communication Research 12(4), 511-529.

Zaller, J. (1992). The Nature and Origins of Mass Opinion. New York: Cambridge University Press.

Zaller, J. (2004). Floating voters in U.S. presidential election, 1948-2000. In P.M. Sniderman \& W.E. Saris (Eds.), Studies in public opinion (pp. 166-212). Princeton, NJ: Princeton University Press. 


\begin{tabular}{|c|c|c|c|c|c|}
\hline \multirow[b]{2}{*}{ Recall Method } & \multicolumn{3}{|c|}{ Panel Method } & \multirow[b]{2}{*}{$\begin{array}{l}\% \text { of } \\
\text { Total }\end{array}$} & \multirow[b]{2}{*}{$\mathrm{N}$} \\
\hline & $\begin{array}{c}\text { Early } \\
\text { Deciders } \\
(\%) \\
\end{array}$ & $\begin{array}{c}\text { Campaign } \\
\text { Deciders } \\
(\%) \\
\end{array}$ & $\begin{array}{c}\text { Late } \\
\text { Deciders } \\
(\%) \\
\end{array}$ & & \\
\hline Early Deciders & 94.5 & 3.4 & 2.1 & 55.0 & 2,165 \\
\hline Campaign Deciders & 80.8 & 18.2 & 1.0 & 31.7 & 1,245 \\
\hline Late Deciders & 40.2 & 17.2 & 42.6 & 13.3 & 523 \\
\hline$\%$ of Total & 83.0 & 9.9 & 7.1 & 100 & \\
\hline $\mathrm{N}$ & 3,263 & 390 & 280 & & 3,933 \\
\hline
\end{tabular}




\begin{tabular}{|c|c|c|c|c|c|c|c|c|c|c|c|}
\hline \multirow{4}{*}{$\begin{array}{r}\text { Party Strength (mean) } \\
\text { Political Knowledge } \\
\text { (mean) }\end{array}$} & \multicolumn{3}{|c|}{ Panel Method } & \multicolumn{3}{|c|}{ Recall Method } & \multicolumn{4}{|c|}{ Combined Method } & \multirow{2}{*}{$\begin{array}{l}\text { All Voters } \\
\\
\text { All Voters } \\
\text { Combined } \\
(\mathrm{N}=3,963)\end{array}$} \\
\hline & $\begin{array}{c}\text { Early } \\
\text { Deciders } \\
(\mathrm{N}=3,268)\end{array}$ & $\begin{array}{l}\text { Campaign } \\
\text { Deciders } \\
(\mathrm{N}=390)\end{array}$ & $\begin{array}{c}\text { Late } \\
\text { Deciders } \\
(\mathrm{N}=280)\end{array}$ & $\begin{array}{c}\text { Early } \\
\text { Deciders } \\
(\mathrm{N}=2,173)\end{array}$ & $\begin{array}{c}\text { Campaign } \\
\text { Deciders } \\
(\mathrm{N}=1,253) \\
\end{array}$ & $\begin{array}{c}\text { Late } \\
\text { Deciders } \\
(\mathrm{N}=531) \\
\end{array}$ & $\begin{array}{c}\text { Early } \\
\text { Deciders } \\
(\mathrm{N}=2,047)\end{array}$ & $\begin{array}{c}\text { Uncommitted } \\
\text { Early } \\
\text { Deciders } \\
(\mathrm{N}=1,216) \\
\end{array}$ & $\begin{array}{l}\text { Campaign } \\
\text { Deciders } \\
(\mathrm{N}=390)\end{array}$ & $\begin{array}{c}\text { Late } \\
\text { Deciders } \\
(\mathrm{N}=280)\end{array}$ & \\
\hline & 2.12 & 1.61 & 1.59 & 2.20 & 1.90 & 1.60 & 2.23 & 1.93 & 1.61 & 1.59 & 2.03 \\
\hline & 1.73 & 1.04 & 0.86 & 1.81 & 1.46 & 1.02 & 1.87 & 1.49 & 1.04 & 0.86 & 1.59 \\
\hline $\begin{array}{r}\text { \# News Sources } \\
\text { (mean) }\end{array}$ & 3.62 & 3.28 & 3.23 & 3.71 & 3.42 & 3.24 & 3.75 & 3.40 & 3.28 & 3.23 & 3.56 \\
\hline Age (mean) & 51.25 & 50.66 & 51.41 & 51.53 & 51.11 & 49.98 & 51.48 & 50.80 & 50.66 & 51.41 & 51.21 \\
\hline$\%$ Male & 45.78 & 39.49 & 45.36 & 47.49 & 41.66 & 44.26 & 47.53 & 42.93 & 39.49 & 45.36 & 45.17 \\
\hline$\%$ Black & 8.94 & 3.85 & 5.00 & 9.25 & 7.34 & 5.27 & 9.62 & 7.73 & 3.85 & 5.00 & 8.13 \\
\hline$\%$ Hispanic & 4.59 & 4.62 & 6.79 & 4.92 & 4.31 & 5.08 & 4.59 & 4.61 & 4.62 & 6.79 & 4.74 \\
\hline Income (mean) & 12.17 & 11.92 & 11.57 & 12.22 & 12.01 & 11.82 & 12.30 & 11.96 & 11.92 & 11.57 & 12.09 \\
\hline $\begin{array}{r}\text { Years Education } \\
\text { (mean) }\end{array}$ & 15.02 & 14.47 & 14.47 & 15.11 & 14.76 & 14.59 & 15.17 & 14.78 & 14.47 & 14.47 & 14.93 \\
\hline$\%$ Democrat & 34.33 & 23.59 & 21.07 & 36.45 & 29.85 & 20.53 & 36.88 & 30.10 & 23.59 & 21.07 & 32.20 \\
\hline$\%$ Republican & 35.10 & 24.87 & 25.00 & 36.40 & 30.81 & 27.12 & 36.74 & 32.32 & 24.87 & 25.00 & 33.38 \\
\hline$\%$ Vote Obama & 51.47 & 57.18 & 50.36 & 51.08 & 54.27 & 49.91 & 51.25 & 51.97 & 57.18 & 50.36 & 51.88 \\
\hline $\begin{array}{r}\text { Perception of } \\
\text { Economy (mean) }\end{array}$ & 1.32 & 1.24 & 1.21 & 1.29 & 1.33 & 1.27 & 1.30 & 1.34 & 1.24 & 1.21 & 1.30 \\
\hline $\begin{array}{r}\text { Personal Finances } \\
\text { (mean) }\end{array}$ & 1.47 & 1.41 & 1.38 & 1.48 & 1.47 & 1.38 & 1.48 & 1.45 & 1.41 & 1.38 & 1.46 \\
\hline
\end{tabular}




\begin{tabular}{|c|c|c|c|c|c|c|c|c|c|c|c|c|}
\hline & \multicolumn{6}{|c|}{ Panel Method } & \multicolumn{6}{|c|}{ Recall Method } \\
\hline & \multicolumn{2}{|c|}{$\begin{array}{c}\text { Early Deciders } \\
\text { vs. } \\
\text { Campaign Deciders }\end{array}$} & \multicolumn{2}{|c|}{$\begin{array}{l}\text { Early Deciders } \\
\text { vs. } \\
\text { Late Deciders } \\
\end{array}$} & \multicolumn{2}{|c|}{$\begin{array}{c}\text { Campaign Deciders } \\
\text { vs. } \\
\text { Late Deciders } \\
\end{array}$} & \multicolumn{2}{|c|}{$\begin{array}{c}\text { Early Deciders } \\
\text { vs. } \\
\text { Campaign Deciders } \\
\end{array}$} & \multicolumn{2}{|c|}{$\begin{array}{c}\text { Early Deciders } \\
\text { vs. } \\
\text { Late Deciders } \\
\end{array}$} & \multicolumn{2}{|c|}{$\begin{array}{c}\text { Campaign Deciders } \\
\text { vs. } \\
\text { Late Deciders } \\
\end{array}$} \\
\hline & b(s.e.) & $\exp (b)$ & b(s.e.) & $\exp (b)$ & b(s.e.) & $\exp (b)$ & b(s.e.) & $\exp (b)$ & b(s.e.) & $\exp (b)$ & b(s.e.) & $\exp (\mathrm{b})$ \\
\hline Party Strength & $-.83(.15)^{* * *}$ & 0.44 & $-.67(.17)^{* * *}$ & 0.51 & $.16(.21)$ & 1.17 & $-.46(.09)^{* * *}$ & 0.63 & $-.86(.13)^{* * *}$ & 0.42 & $-.40(.14)^{* *}$ & 0.67 \\
\hline $\begin{array}{r}\text { Political } \\
\text { Knowledge }\end{array}$ & $-.61(.06)^{* * *}$ & 0.54 & $-.82(.08)^{* * *}$ & 0.44 & $-.20(.09)^{*}$ & 0.82 & $-.28(.04)^{* * *}$ & 0.76 & $-.67(.06)^{* * *}$ & 0.51 & $-.40(.06)^{* * *}$ & 0.67 \\
\hline \# News Sources & $-.05(.04)$ & 0.96 & $-.05(.05)$ & 0.95 & $.00(.06)$ & 1.00 & $-.10(.03)^{* * *}$ & 0.91 & $-.11(.04)^{* *}$ & 0.90 & $-.01(.04)$ & 0.99 \\
\hline Age & $.00(.00)$ & 1.00 & $.00(.01)$ & 1.00 & $.00(.01)$ & 1.00 & $.00(.00)$ & 1.00 & $.00(.00)$ & 1.00 & $-.01(.00)$ & 0.99 \\
\hline Gender (Male) & $-.17(.12)$ & 0.84 & $.12(.14)$ & 1.13 & $.29(.17)$ & 1.33 & $-.21(.08)^{* *}$ & 0.81 & $-.04(.11)$ & 0.96 & $.16(.11)$ & 1.18 \\
\hline Black & $-1.04(.29)^{* * *}$ & 0.35 & $-.62(.31)^{*}$ & 0.54 & $.43(.41)$ & 1.53 & $-.35(.15)^{*}$ & 0.70 & $-.60(.23)^{*}$ & 0.55 & $-.25(.24)$ & 0.78 \\
\hline Hispanic & $-.19(.27)$ & 0.83 & $.27(.28)$ & 1.32 & $.46(.35)$ & 1.58 & $-.29(.18)$ & 0.75 & $-.18(.24)$ & 0.84 & $.11(.25)$ & 1.11 \\
\hline Income & $.02(.02)$ & 1.02 & $.00(.02)$ & 1.00 & $-.02(.02)$ & 0.98 & $.01(.01)$ & 1.01 & $.00(.02)$ & 1.00 & $-.01(.02)$ & 0.99 \\
\hline Years Education & $-.07(.03)^{*}$ & 0.93 & $-.04(.03)$ & 0.96 & $.03(.04)$ & 1.03 & $-.04(.02)^{*}$ & 0.96 & $-.04(.03)$ & 0.96 & $.01(.03)$ & 1.01 \\
\hline Democrat & $.43(.27)$ & 1.54 & $.15(.32)$ & 1.16 & $-.28(.38)$ & 0.76 & $.18(.18)$ & 1.20 & $.24(.25)$ & 1.27 & $.05(.26)$ & 1.06 \\
\hline Republican & $.66(.25)^{* *}$ & 1.94 & $.36(.30)$ & 1.43 & $-.31(.36)$ & 0.74 & $.33(.17)$ & 1.39 & $.55(.24)^{*}$ & 1.74 & $.22(.24)$ & 1.25 \\
\hline $\begin{array}{r}\text { Vote Choice } \\
\text { (Obama) }\end{array}$ & $.56(.14)^{* * *}$ & 1.75 & $.27(.16)$ & 1.31 & $-.30(.19)$ & 0.74 & $.40(.10)^{* * *}$ & 1.49 & $.34(.13)^{* *}$ & 1.40 & $-.06(.13)$ & 0.94 \\
\hline $\begin{array}{r}\text { Perception of } \\
\text { Economy }\end{array}$ & $-.12(.10)$ & 0.89 & $-.28(.12)^{*}$ & 0.76 & $-.16(.15)$ & 0.85 & $.18(.06)^{* *}$ & 1.20 & $.05(.09)$ & 1.05 & $-.14(.09)$ & 0.87 \\
\hline Personal Finances & $-.04(.06)$ & 0.96 & $-.05(.07)$ & 0.95 & $-.01(.08)$ & 0.99 & $.01(.04)$ & 1.01 & $-.06(.05)$ & 0.94 & $-.07(.05)$ & 0.93 \\
\hline Constant & $.95(.52)$ & & $.57(.60)$ & & $-.38(.72)$ & & $1.13(.34)^{* * *}$ & & $2.00(.47)^{* * *}$ & & $.87(.49)$ & \\
\hline$N$ & 3,787 & & & & & & 3,805 & & & & & \\
\hline Nagelkerke $R^{2}$ & .18 & & & & & & .15 & & & & & \\
\hline $\begin{array}{l}* \mathrm{p}<.05 ; * * \mathrm{p}<.01 ; * \\
\text { Source: } 2008 \text { Nation } \\
\text { Note: Analysis comp } \\
\text { category. }\end{array}$ & $\begin{array}{l}<.001 \\
\text { nnenberg E } \\
\text { s of two mu }\end{array}$ & on Su & $\begin{array}{l}\text { NAES) I } \\
\text { c regress }\end{array}$ & $\mathrm{Pc}$ & mpone & 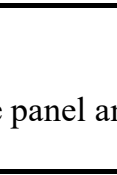 & 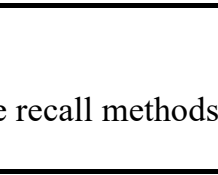 & . & 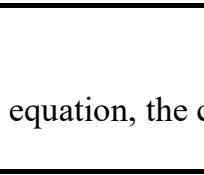 & . & 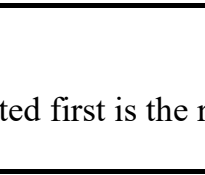 & ence \\
\hline
\end{tabular}




\begin{tabular}{|c|c|c|c|c|c|c|c|c|c|c|c|c|}
\hline & \multicolumn{2}{|c|}{$\begin{array}{c}\text { Early Deciders } \\
\text { vs. } \\
\text { Uncommitted Early } \\
\end{array}$} & \multicolumn{2}{|c|}{$\begin{array}{c}\text { Early Deciders } \\
\text { vs. } \\
\text { Campaign Deciders }\end{array}$} & \multicolumn{2}{|c|}{$\begin{array}{c}\text { Early Deciders } \\
\text { vs. } \\
\text { Late Deciders }\end{array}$} & \multicolumn{2}{|c|}{$\begin{array}{c}\text { Uncommitted Early } \\
\text { vs. } \\
\text { Campaign Deciders }\end{array}$} & \multicolumn{2}{|c|}{$\begin{array}{c}\text { Uncommitted Early } \\
\text { vs. } \\
\text { Late Deciders } \\
\end{array}$} & \multicolumn{2}{|c|}{$\begin{array}{c}\text { Campaign Deciders } \\
\text { vs. } \\
\text { Late Deciders } \\
\end{array}$} \\
\hline & $b$ (s.e.) & $\exp (b)$ & $b$ (s.e.) & $\exp (b)$ & $b$ (s.e.) & $\exp (b)$ & $b($ s.e. $)$ & $\exp (b)$ & $b$ (s.e.) & $\exp (b)$ & b(s.e.) & $\exp (b)$ \\
\hline Party Strength & $-.50(.09)^{* * *}$ & 0.61 & $-1.04(.15)^{* * *}$ & 0.35 & $-.89(.18)^{* * *}$ & 0.41 & $-.55(.15)^{* *}$ & 0.58 & $-.39(.18)^{*}$ & 0.68 & $.16(.21)$ & 1.17 \\
\hline $\begin{array}{r}\text { Political } \\
\text { Knowledge }\end{array}$ & $-.31(.04)^{* * *}$ & 0.74 & $-.75(.07)^{* * *}$ & 0.47 & $-.95(.08)^{* * *}$ & 0.39 & $-.44(.07)^{* * *}$ & 0.64 & $-.64(.08)^{* * *}$ & 0.53 & $-.20(.09)^{*}$ & 0.82 \\
\hline \# News Sources & $-.11(.03)^{* * *}$ & 0.90 & $-.10(.04)^{*}$ & 0.91 & $-.10(.05)^{*}$ & 0.91 & $.01(.04)$ & 1.01 & $.01(.05)$ & 1.01 & $.00(.06)$ & 1.00 \\
\hline Age & $.00(.00)$ & 1.00 & $.00(.00)$ & 1.00 & $.00(.01)$ & 1.00 & $.00(.00)$ & 1.00 & $.00(.01)$ & 1.00 & $.00(.01)$ & 1.00 \\
\hline Gender (Male) & $-.15(.08)$ & 0.86 & $-.24(.12)$ & 0.79 & $.05(.14)$ & 1.05 & $-.09(.13)$ & 0.91 & $.19(.14)$ & 1.21 & $.29(.17)$ & 1.33 \\
\hline Black & $-.34(.15)^{*}$ & 0.72 & $-1.20(.30)^{* * *}$ & 0.30 & $-.77(.32)^{*}$ & 0.46 & $-.86(.31)^{* *}$ & 0.42 & $-.44(.32)$ & 0.65 & $.42(.41)$ & 1.53 \\
\hline Hispanic & $-.11(.18)$ & 0.89 & $-.24(.28)$ & 0.79 & $.22(.29)$ & 1.25 & $-.13(.29)$ & 0.88 & $.33(.29)$ & 1.40 & $.46(.35)$ & 1.58 \\
\hline Income & $.00(.01)$ & 1.00 & $.02(.02)$ & 1.02 & $.00(.02)$ & 1.00 & $.02(.02)$ & 1.02 & $-.01(.02)$ & 1.00 & $-.02(.02)$ & 0.98 \\
\hline Years Education & $-.05(.02)^{*}$ & 0.96 & $-.10(.03)^{* *}$ & 0.91 & $-.06(.04)$ & 0.94 & $-.05(.03)$ & 0.95 & $-.02(.04)$ & 0.98 & $.03(.04)$ & 1.03 \\
\hline Democrat & $.29(.18)$ & 1.33 & $.54(.28)$ & 1.72 & $.26(.33)$ & 1.30 & $.26(.28)$ & 1.29 & $-.02(.33)$ & 0.98 & $-.28(.38)$ & 0.76 \\
\hline Republican & $.40(.18)^{*}$ & 1.49 & $.83(.27)^{* *}$ & 2.29 & $.52(.31)$ & 1.69 & $.43(.27)$ & 1.54 & $.13(.31)$ & 1.14 & $-.30(.36)$ & 0.74 \\
\hline $\begin{array}{r}\text { Vote Choice } \\
\text { (Obama) }\end{array}$ & $.31(.10)^{* *}$ & 1.36 & $.71(.15)^{* * *}$ & 2.03 & $.41(.17)^{*}$ & 1.51 & $.40(.15)^{* *}$ & 1.49 & $.10(.17)$ & 1.11 & $-.29(.19)$ & 0.75 \\
\hline $\begin{array}{r}\text { Perception of } \\
\text { Economy }\end{array}$ & $.17(.07)^{* *}$ & 1.19 & $-.04(.11)$ & 0.96 & $-.20(.13)$ & 0.82 & $-.21(.11)$ & 0.81 & $-.37(.13)^{* *}$ & 0.69 & $-.16(.15)$ & 0.85 \\
\hline $\begin{array}{l}\text { Personal } \\
\text { Finances }\end{array}$ & $-.01(.04)$ & 0.99 & $-.04(.06)$ & 0.96 & $-.05(.07)$ & 0.95 & $-.03(.06)$ & 0.97 & $-.04(.07)$ & 0.96 & $-.01(.08)$ & 0.99 \\
\hline Constant & $1.59(.35)^{* * *}$ & & $2.39(.54)^{* * *}$ & & $2.02(.62)^{* *}$ & & $.79(.55)$ & & $.43(.63)$ & & $-.37(.72)$ & \\
\hline$N$ & 3,783 & & & & & & & & & & & \\
\hline Nagelkerke $R^{2}$ & .19 & & & & & & & & & & & \\
\hline
\end{tabular}

